\title{
Diel vertical migration and distribution of zooplankton in a tropical Brazilian reservoir
}

\author{
Ana M. A. da Silva ${ }^{1 *}$ \\ Paulo Roberto de Medeiros ${ }^{2}$ \\ Maria C. B. C. da Silva ${ }^{2}$ \\ José E. L. Barbosa ${ }^{1}$ \\ ${ }^{1}$ Departamento de Biologia, Centro de Ciências Biológicas e da Saúde \\ Universidade Estadual da Paraíba \\ Av. das Baraúnas 351, CEP 58100-001, Campina Grande- PB, Brazil \\ ${ }^{2}$ Departamento de Sistemática e Ecologia, Centro de Ciências Exatas e da Natureza \\ Universidade Federal da Paraíba, Cidade Universitária, Campus I \\ CEP 58059-900, João Pessoa - PB, Brazil \\ *Author for correspondence \\ ana.maria.bio@gmail.com
}

Submetido em 13/05/2008

Aceito para publicação em 23/09/2008

\section{Resumo}

Migração vertical e distribuição do zooplâncton em um açude tropical brasileiro. A migração vertical diária do zooplâncton é uma estratégia geralmente utilizada para reduzir o risco de predação, mas que pode também se associar às mudanças de dia/noite do ambiente, principalmente luz e temperatura. O objetivo desse trabalho foi identificar padrões diários de migração vertical das populações zooplanctônicas e suas relações com as variáveis ambientais em um açude raso localizado no nordeste do Brasil. As amostras de água foram amostradas em quatro profundidades (Sub-superfície, 50\% I, 1\% I e Fundo) em uma estação de amostragem com cinco metros de profundidade, em intervalos de quatro horas, ao longo de 24 horas. Duas espécies de Cladocera (Moina minuta e Diaphanosoma spinulosum) e uma espécie de Copepoda (Notodiaptomus cearensis) apresentaram padrões relativamente semelhantes de migração noturna, permanecendo no fundo durante o dia e se deslocando próximo à superfície no fim da tarde e ao longo da noite. Brachionus falcatus e Hexarthra mira (Rotifera) não apresentaram padrões migratórios e as suas distribuições verticais foram relativamente homogêneas. As variáveis ambientais e as distribuições das espécies correlacionaram-se fracamente, sugerindo que outros mecanismos podem ser responsáveis por induzir a migração vertical.

Unitermos: açude, Cladocera, Copepoda, Rotifera, migração diária, semi-árido

\section{Abstract}

Diel vertical migration of zooplankton is a strategy usually employed to reduce the risk of predation, and it can also be associated with the environmental day/night shifts, particularly of light and temperature. The aim of this study was to identify the diel patterns of zooplankton vertical migration and their relationship to the environmental variables in a shallow reservoir in northeastern Brazil. Water samples were taken at a single five-meter depth sampling station (Subsurface, 50\% $\mathrm{I}_{0}, 1 \% \mathrm{I}_{\mathrm{o}}$ and Bottom) at four-hour intervals over a period 
of 24 hours. Two Cladocera species (Moina minuta and Diaphanosoma spinulosum) and one Copepoda species (Notodiaptomus cearensis) showed similar patterns of nocturnal migration, staying at the bottom during the day and rising toward the surface in the afternoon and during the night. Brachionus falcatus and Hexarthra mira (Rotifera) showed no patterns of vertical migration and their vertical distributions were relatively homogenous. Environmental variables were poorly correlated to the species distribution, suggesting that other mechanisms may be responsible of inducing vertical migration.

Key words: Cladocera, Copepoda, Rotifera, diel migration, semi-arid

\section{Introduction}

The vertical migration of zooplankton is a well studied behavior in many freshwater environments (e.g. Buchanan and Haney, 1980; Iwasa, 1982; Dodson, 1990; Tomm et al., 1992; Sekino and Yamamura, 1999; Perticarrari et al., 2004). However, there is no consensus regarding the adaptive benefits of vertical migration to the zooplankton individuals (Perticarrari et al., 2004), although this behavior is frequently considered to be a strategy employed to reduce their risk of predation (Sekino and Yamamura, 1999). Furthermore, vertical migration can be influenced by environmental fluctuation which is, thereby, highly correlated to the diel light variation. Thus, the zooplankton community may respond to this variation and optimize food resources use, during a favorable period and at a particular depth, resulting in a periodic and synchronized vertical migration behavior (MatsumuraTundisi et al., 1984; Haney et al., 1990). Regardless of the benefits of vertical migration, this behavior is clearly triggered by many factors. For example, the light-dark cycle and the temperature variation during the day are the most important (Hutchinson, 1967; Buchanan and Haney, 1980; Dodson, 1990; Haney et al., 1990). The presence of a thermocline (Zaret and Suffern, 1976; Matsumura-Tundisi et al., 1984) or an oxicline (Fisher et al., 1983; Matsumura-Tundisi et al., 1984; Tomm et al., 1992), food concentration (Meyers, 1980), pH variation (Bayly, 1963) and chemical stimuli (Dawidowicz et al., 1990) are also ecological factors that have strong influence on the distribution and vertical migration of zooplankton.

There are few studies on the abundance and distribution of zooplankton in the shallow tropical reservoirs of the northeastern semi-arid regions of Brazil (e.g. Fisher et al., 1983; Nogueira and Panarelli, 1997;
Perticarrari et al., 2004). Despite the importance of the studied area to Brazilian limnology, a limited number of investigations have been accomplished (see Moredjo, 1998), the present study being the first to investigate migration movements in this environment. Although well documented, the significance of vertical migration may differ spatially and be species-specific (Ohman, 1990), thus supporting the need for local investigations. Therefore, the aims of this study were to identify the diel patterns of vertical migration of the zooplankton community and to investigate whether these patterns are related to the daily shifts of the environmental variables in a shallow tropical Brazilian reservoir of a semi-arid region.

\section{Material and Methods}

\section{Study area}

The Bodocongó reservoir ( $\left.7^{\circ} 13^{\prime} 11^{\prime \prime} \mathrm{S}, 35^{\circ} 52^{\prime} 31^{\prime \prime} \mathrm{W}\right)$ is located in Campina Grande city, Paraiba State, Northeastern Brazil, 550m above sea level (Alves et al., 2002) (Figure 1). The reservoir has a maximum depth of $6.5 \mathrm{~m}$ (average depth: $3 \mathrm{~m}$ ), a surface area of approximately $150,000 \mathrm{~m}^{2}$, and a maximum water capacity of $873,308 \mathrm{~m}^{3}$. It was originally built in 1917 in order to provide an additional water supply for the city of Campina Grande. Nowadays, the Bodocongó reservoir is mostly used by fishermen and people living nearby, but its water is considered to be inadequate for human use. Historically, the first Brazilian limnological research was carried out at the Bodocongó reservoir (e.g. Wright, 1934 and 1936), considered today to be the birthplace of Brazilian limnology (Esteves, 1998). 


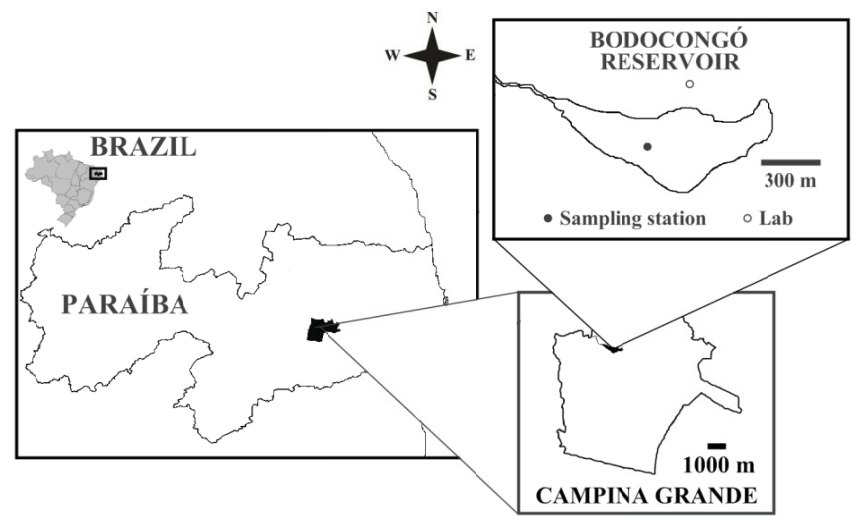

FIGURE 1: Location of the Bodocongó reservoir and the sampling station.

\section{Sampling}

Water samples were collected in the dry season in November 2003. Four depths (Subsurface, 50\% I, 1\% $\mathrm{I}_{\mathrm{o}}$, and Bottom; $I_{o}$ is the irradiance at the surface) were collected at one five-meter depth sampling station at fourhour intervals $\left(1_{\mathrm{pm}}, 5_{\mathrm{pm}}, 9_{\mathrm{pm}}, 1_{\mathrm{am}}, 5_{\mathrm{am}}, 9_{\mathrm{am}}\right.$ and $\left.1_{\mathrm{pm}}\right)$ over a period of 24 hours. Samples were collected at depths reflecting a light penetration gradient to evaluate the influence of light on species distribution. The coefficient of vertical attenuation of light was calculated on the basis of three water transparency measurements made prior to the beginning of the study (morning, early afternoon and late afternoon) using the procedures described by Esteves (1998). The mean values of the 50\% $\mathrm{I}_{\mathrm{o}}$ and $1 \%$ $\mathrm{I}_{\mathrm{o}}$ depths were 0.5 and $1.8 \mathrm{~m}$, respectively.

Water samples for evaluations of the zooplankton and environmental variables were collected using a $5 \mathrm{~L}$ Van Dorn bottle. A total of 40L was filtered through a plankton net $(30 \mu \mathrm{m}$ mesh size $)$ and the zooplankton samples were preserved in formaldehyde $4 \%$ saturated with sugar (Haney and Hall, 1973). Identification of species was based on specialized literature (Harding and Smith, 1974; Rocha and Matsumura-Tundisi, 1976; Pennak, 1978; Reid, 1985; Korovchinsky, 1992; Dussart and Defaye, 1995) and the individuals were counted using a Sedgwick-Rafter counting chamber. A minimum of 100 individuals were considered, and three sub-samples were taken from each sample.

Physical and chemical variables (water transparency, water temperature, alkalinity, electric conductivity, $\mathrm{pH}$, dissolved oxygen, total nitrogen and total phosphorous) were obtained at the same depths and intervals considered for the zooplankton study. A summary of the methods used is shown in Table 1. The nictemeral dynamic of these variables was discussed at length by Medeiros et al. (2007).

TABLE 1: Methods used to estimate the physical and chemical variables in the Bodocongó reservoir, Paraíba, Brazil.

\begin{tabular}{llc}
\hline \multicolumn{1}{c}{ Variables } & \multicolumn{1}{c}{ Material and/or Methods } & Unit \\
\hline Water transparency & Secchi disk $(30 \mathrm{~cm}$ in diameter $)$ & $\mathrm{m}$ \\
Water temperature & Thermometer $\left(0.5^{\circ} \mathrm{C}\right.$ precision $)$ & ${ }^{\circ} \mathrm{C}$ \\
Alkalinity & Golterman et al. (1978) & $\mathrm{mg} . \mathrm{L}^{-1}$ \\
Electric conductivity & Cole Palmer conductivimeter & $\mu \mathrm{S} . \mathrm{cm}^{-1}$ \\
pH & Hanna HI 9224 pHmeter & - \\
Dissolved oxygen & Winkler method & $\mathrm{mg} . \mathrm{L}^{-1}$ \\
Total nitrogen & Mackereth et al. (1978) and & $\mu \mathrm{g} . \mathrm{L}^{-1}$ \\
Total phosphorus & Rodier (1975) & APHA (1995) \\
\hline
\end{tabular}

\section{Data Analysis}

Analysis of variance (one-way ANOVA) was applied to test the differences among independent groups (physical and chemical variables) on the spatial (depth) and temporal (time) scales studied. Pearson correlation analysis was used to investigate the relationships between the environmental variables and species abundance. Prior to the analysis, normality (Shapiro-Wilk test) and homogeneity (Levene's test) were tested and, when necessary, the data was $\log (\mathrm{x}+1)$ transformed. In every case, tests were considered significant at $\mathrm{p}<0.05$.

The analyses were carried out using Statistica ${ }^{\circledR}$ software, and values of the environmental variables were converted into isoline graphs using the Surfer software.

\section{Results}

A total of 12 species were identified: Moina minuta, Diaphanosoma spinulosum, Ceriodaphnia cornuta (Cladocera), Notodiaptomus cearensis (Copepoda), Brachionus falcatus, B. calyciflorus, B. dolabratus, B. urceolaris, Brachionus sp., Hexarthra mira, Filinia longiseta and Keratella sp. (Rotifera). Notodiaptomus 
cearensis was the most abundant species $(60 \%$ of the zooplankton abundance), followed by $H$. mira (15\%), B. falcatus (12\%), M. minuta (4\%) and D. spinulosum (3\%). The other seven species represented $6 \%$ of zooplankton abundance (Table 2) and were excluded from the analyses. Thus, only five species (M. minuta, D. spinulosum, $N$. cearensis, B. falcatus and $H$. mira) were evaluated.

Values of the physical and chemical variables are shown in Figure 2. No significant spatial (depth) or temporal (time) variations were found for the physical and chemical variables sampled (ANOVA, $p>0.05$ ), with the exception of the alkalinity values, which increased as the study carried on (d.f. $=6 ; \mathrm{p}<0.05$ ). However, a clear trend towards a day/night shift in the values of water temperature, alkalinity, electric conductivity, $\mathrm{pH}$ and dissolved oxygen was observed.

The vertical distribution of $M$. minuta during the 24 hours in the reservoir is shown in Figure 3. At $1_{\mathrm{pm}}$, most individuals (48\%) were found at the Bottom; at $5_{\mathrm{pm}}$ and $9_{\mathrm{pm}}$ they were mostly located in the two upper layers of the water column $(>70 \%)$, but later $\left(1_{\mathrm{am}}\right)$ they returned to the Bottom (62\%). After this time, a relatively homogenous distribution of the individuals was observed at all depths during the morning ( $5_{\text {am }}$ to 9 am $)$. During the last hour of the study $\left(1_{\mathrm{pm}}\right)$, the distribution of this species was similar to that observed in the first hour $\left(1_{\mathrm{pm}}\right)$, with most of the individuals (60\%) found at the Bottom (Figure 3).

Individuals of $D$. spinulosum showed a relatively similar pattern of vertical distribution (Figure 4) to that of M. minuta. At $1_{\mathrm{pm}}$ the individuals were distributed mainly at the $1 \% \mathrm{I}_{\mathrm{o}}$ and Bottom depths $(87 \%)$. At $5_{\mathrm{pm}}$, they migrated to the upper layers (74\%; Subsurface and $50 \% \mathrm{I}_{\mathrm{o}}$ ), and at $9 \mathrm{pm}$ most of the individuals $(72 \%)$ inhabited the Subsurface and 50\% $\mathrm{I}_{\mathrm{o}}$ depths. At $1_{\text {am }}$ the individuals were mostly located at the Bottom; at $5_{\text {am }}$ a clear distribution pattern was not observed, but at 9 am the individuals migrated back to the deeper layers, where at $1_{\mathrm{pm}}$ most (70\%) occupied the deeper layers of the water column as in the beginning of the study.

TABLE 2: Zooplankton species abundance (individuals per liter) at four depths (Subsurface, $50 \% \mathrm{I}_{\mathrm{o}}, 1 \% \mathrm{I}_{\mathrm{o}}$ and Bottom), during a diel study (four-hour intervals) at the Bodocongo reservoir, northeastern Brazil (Moi min: Moina minuta; Dia spi: Diaphanosoma spinulosum; Cer cor: Ceriodaphnia cornuta; Not cea: Notodiaptomus cearensis; Bra fal: Brachionus falcatus; Bra cal: Brachionus calyciflorus; Bra dol: Brachionus dolabratus; Bra urc: Brachionus urceolaris; Bra sp.: Brachionus sp.; Hex mir: Hexarthra mira; Fil lon: Filinia longiseta; Ker sp.: Keratella sp.).

\begin{tabular}{|c|c|c|c|c|c|c|c|c|c|c|c|c|c|}
\hline \multirow{3}{*}{ Time/Depth } & \multicolumn{13}{|c|}{ Group/Species } \\
\hline & \multicolumn{3}{|c|}{ Cladocera } & \multirow{2}{*}{$\frac{\text { Copepoda }}{\text { Not ceat }}$} & \multicolumn{9}{|c|}{ Rotifexa } \\
\hline & Moi min & Dia spi & $\operatorname{ces} \cos$ & & Bra fal & Bra cal & Bra dol & Bra urc & Bra sp. & Hex mix & Kex sp. & Fil lon & Total \\
\hline \multicolumn{14}{|l|}{ Ipm } \\
\hline $100 \% 10$ & 19.8 & 4.0 & 0.0 & 187.0 & 56.0 & 0.19 & 0.0 & 0.0 & 4.0 & 79.5 & 0.0 & 4.0 & 354.5 \\
\hline $50 \%$ & 5.5 & 3.0 & 0.0 & 0.0 & 47.0 & 5.5 & 2.8 & 0.0 & 0.0 & 0.0 & 0.0 & 5.5 & 69.3 \\
\hline $1 \% 10$ & 13.9 & 35.0 & 0.0 & 139.0 & 59 & 7.0 & 7.0 & 0.0 & 34.8 & 100.8 & 7.0 & 7.0 & 410.5 \\
\hline Bottom & 34.5 & 14.4 & 2.9 & 521.0 & 32.0 & 2.9 & 0.0 & 0.0 & 0.0 & 23.0 & 0.0 & 0.0 & 630.7 \\
\hline \multicolumn{14}{|l|}{ Spm } \\
\hline $100 \% 10$ & 6.2 & 6.2 & 0.0 & 158.1 & 46.5 & 3.1 & 21.7 & 0.0 & 0.0 & 21.7 & 0.0 & 0.0 & 263.5 \\
\hline $50 \%$ & 17.9 & 14.3 & 0.0 & 271.1 & 57.2 & 14.3 & 3.6 & 0.0 & 3.6 & 35.8 & 0.0 & 0.0 & 417.8 \\
\hline $1 \% 10$ & 3.6 & 3.6 & 0.0 & 347.0 & 20.0 & 7.2 & 3.6 & 0.0 & 0.0 & 53.6 & 0.0 & 0.0 & 438.6 \\
\hline Bottom & 4.2 & 8.4 & 0.0 & 34.0 & 79.3 & 4.2 & 4.2 & 0.0 & 0.0 & 41.7 & 0.0 & 4.2 & 180.2 \\
\hline \multicolumn{14}{|l|}{ 9pm } \\
\hline $100 \% \mathbf{I a}$ & 12.3 & 16.4 & 2.1 & 299.3 & 49.2 & 4.1 & 0.0 & 0.0 & 0.0 & 53.3 & 0.0 & 0.0 & 436.7 \\
\hline 50\%Io & 19.1 & 11.5 & 3.8 & 361.8 & 60.0 & 16.6 & 1.3 & 0.0 & 1.3 & 86.1 & 0.0 & 3.8 & 565.3 \\
\hline $1 \% 10$ & 8.4 & 6.0 & 3.6 & 260.4 & 50.4 & 4.8 & 0.0 & 0.0 & 0.0 & 85.2 & 0.0 & 0.0 & 418.8 \\
\hline Bottom & 4.9 & 4.9 & 2.4 & 245.0 & 44.0 & 7.3 & 0.0 & 0.0 & 0.0 & 63.1 & 2.4 & 0.0 & 374 \\
\hline \multicolumn{14}{|l|}{ lam } \\
\hline $100 \%$ & 8.0 & 6.4 & 1.6 & 277.0 & 32.0 & 1.6 & 0.0 & 1.6 & 1.6 & 38.4 & 0.0 & 0.0 & 368.2 \\
\hline $50 \% 10$ & 8.6 & 0.0 & 2.2 & 189.2 & 17.2 & 0.0 & 0.0 & 0.0 & 0.0 & 6.5 & 2.2 & 0.0 & 225.9 \\
\hline $1 \% 10$ & 5.3 & 1.5 & 0.0 & 34.0 & 11.3 & 1.5 & 0.0 & 0.0 & 1.5 & 6.0 & 0.8 & 0.8 & 62.7 \\
\hline Bottom & 33.6 & 12.6 & 6.3 & 558.6 & 58.8 & 6.3 & 0.0 & 2.1 & 0.0 & 113.4 & 0.0 & 8.4 & 800.1 \\
\hline \multicolumn{14}{|l|}{ Sam } \\
\hline $100 \% 10$ & 5.7 & 2.9 & 0.0 & 91.2 & 28.5 & 2.9 & 2.9 & 0.0 & 0.0 & 37.1 & 0.0 & 5.7 & 176.9 \\
\hline $50 \% 10$ & 8.6 & 34.5 & 0.0 & 187.0 & 28.8 & 5.8 & 0.0 & 0.0 & 0.0 & 100.6 & 0.0 & 5.8 & 371.1 \\
\hline $1 \%$ Io & 3.0 & 3.0 & 0.0 & 45.0 & 27.0 & 0.0 & 3.0 & 0.0 & 0.0 & 101.2 & 0.0 & 0.0 & 182.2 \\
\hline Bottom & 8.3 & 33.0 & 0.0 & 239.3 & 44.0 & 0.0 & 0.0 & 0.0 & 0.0 & 112.8 & 0.0 & 0.0 & 437.4 \\
\hline \multicolumn{14}{|l|}{9 am } \\
\hline $100 \% 10$ & 24.1 & 5.4 & 0.0 & 102.0 & 56.2 & 5.4 & 0.0 & 0.0 & 0.0 & 37.5 & 2.7 & 2.7 & 236,0 \\
\hline $50 \% 10$ & 20.0 & 6.7 & 0.0 & 115.7 & 53.4 & 0.0 & 0.0 & 0.0 & 0.0 & 40.1 & 2.2 & 4.5 & 242.6 \\
\hline $1 \%$ Io & 24.20 & 13.2 & 0.0 & 220 & 48.4 & 8.8 & 0.0 & 0.0 & 0.0 & 66.0 & 0.0 & 0.0 & 380.6 \\
\hline Bottom & 25.40 & 9.5 & 0.0 & 210.0 & 67.0 & 15.9 & 0.0 & 0.0 & 0.0 & 66.7 & 6.4 & 3.2 & 404.1 \\
\hline \multicolumn{14}{|l|}{ 1pm } \\
\hline $100 \% 1 \mathrm{a}$ & 4.4 & 4.4 & 0.0 & 167.5 & 59.0 & 2.2 & 0.0 & 0.0 & 0.0 & 78.3 & 2.2 & 2.2 & 320.2 \\
\hline $50 \% 10$ & 11.0 & 5.5 & 1.8 & 170.0 & 91.3 & 3.7 & 0.0 & 0.0 & 1.8 & 74.8 & 1.8 & 1.8 & 363.5 \\
\hline $1 \%$ & 19.3 & 7.0 & 1.8 & 506.0 & 78.8 & 0.0 & 1.8 & 0.0 & 0.0 & 68.3 & 3.5 & 1.8 & 688.3 \\
\hline Bottom & 48.9 & 23.17 & 5.2 & 721.0 & 85.0 & 10.3 & 2.6 & 0.0 & 0.0 & 141.6 & 0.0 & 7.7 & 1045.5 \\
\hline Total & 408.7 & 296.5 & 33.7 & 6657.2 & 1387.3 & 141.6 & 54.5 & 3.7 & 48.6 & 1733.1 & 31.2 & 69.1 & $10,865.2$ \\
\hline
\end{tabular}




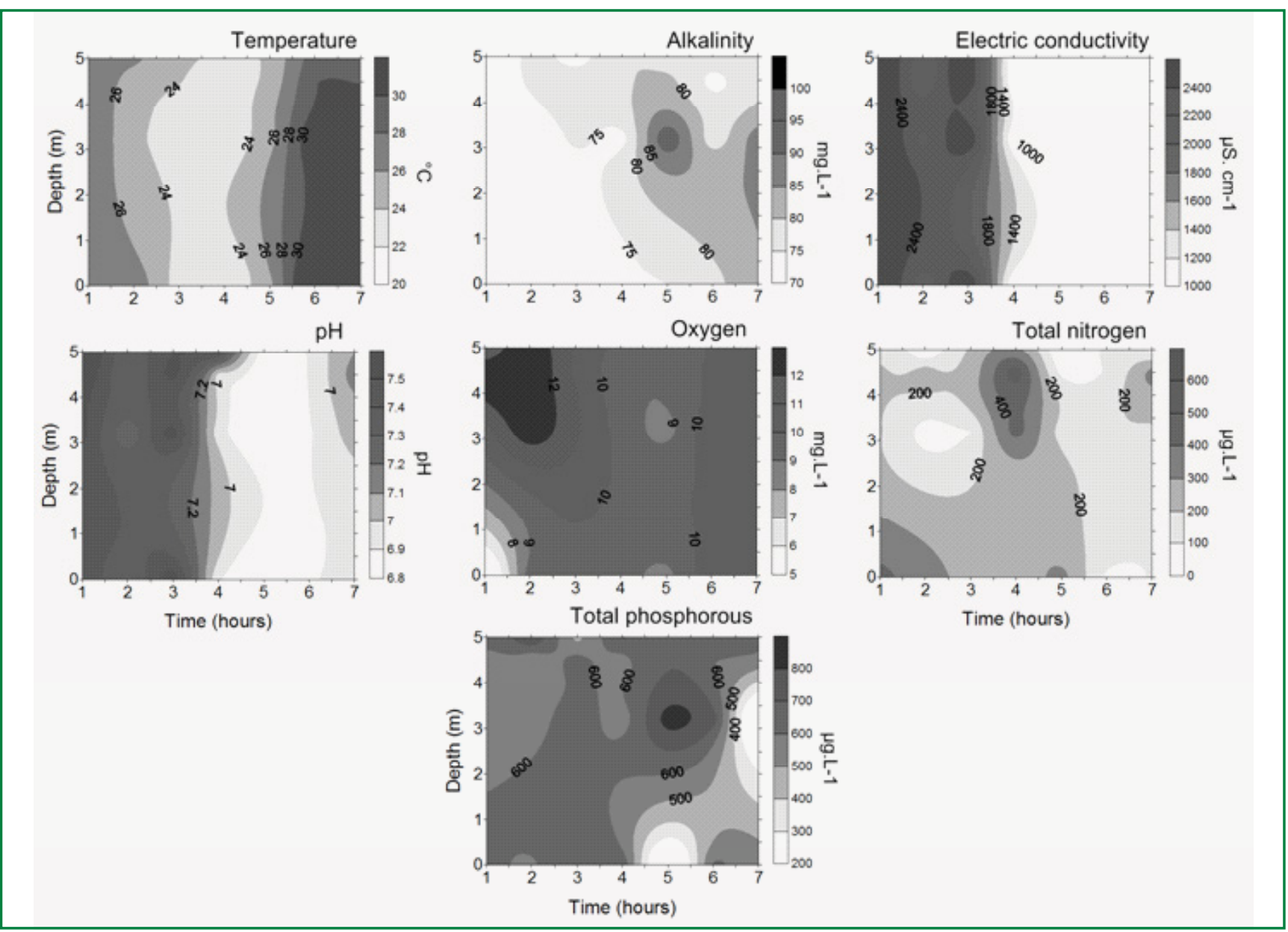

FIGURE 2: Isolines of water temperature, alkalinity, electric conductivity, $\mathrm{pH}$, dissolved oxygen, total nitrogen and total phosphorous measured at four depths (Subsurface, 50\% $\mathrm{I}_{0}, 1 \% \mathrm{I}_{\mathrm{o}}$ and Bottom) along four-hour intervals during a diel study at the Bodocongo reservoir, northeastern Brazil.

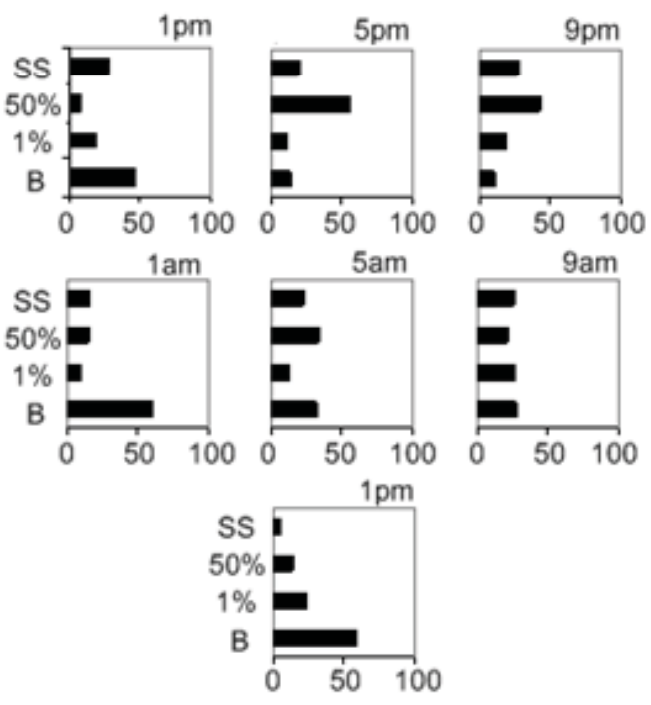

FIGURE 3: Vertical abundance and distribution (\%) of Moina minuta during a diel study at the Bodocongó reservoir, northeastern Brazil. SS = Subsurface; $50 \%=50 \% \mathrm{I}$; $1 \%=1 \% \mathrm{I}_{\mathrm{o}} ; \mathrm{B}=$ Bottom

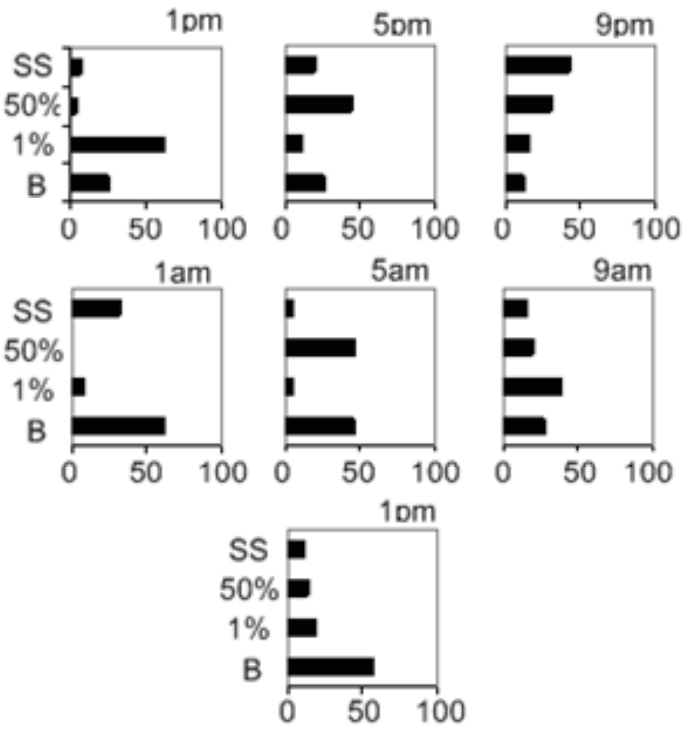

FIGURE 4: Vertical abundance and distribution (\%) of Diaphanosom spinulosum during a diel study at the Bodocongó reservoir, northeastern Brazil. Refer to Figure 3 for legend details. 
The copepod $N$. cearensis showed an equivalent pattern of distribution (Figure 5) to that of the cladoceran species. At $1_{\mathrm{pm}}$ most individuals were distributed at the Bottom (62\%), but at $5_{\mathrm{pm}}$ and $9_{\mathrm{pm}}$ they showed a relatively homogenous vertical distribution. At $1_{\text {am }}$ they were distributed mainly at the Bottom (50\%). This trend was also observed in the subsequent intervals $\left(5_{\mathrm{am}}, 9_{\mathrm{am}}\right.$ and $\left.1_{\mathrm{pm}}\right)$. A significant positive correlation between $M$. minuta and $N$. cearensis distribution was obtained with the Pearson correlation $(\mathrm{r}=0.72 ; \mathrm{p}<0.05)$.
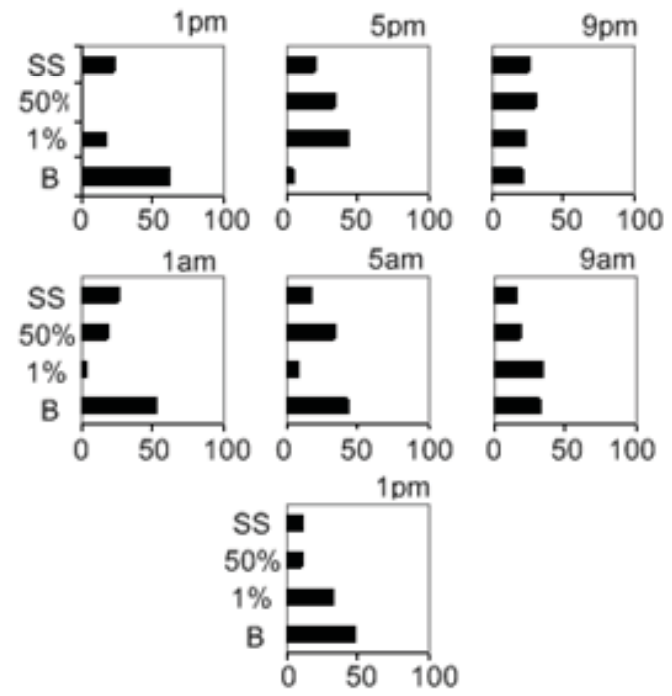

FIGURE 5: Vertical abundance and distribution (\%) of Notodiaptomus cearensis during a diel study at the Bodocongó reservoir, northeastern Brazil. Refer to Figure 3 for legend details.

The distribution of the $B$. falcatus individuals was relatively homogenous, with slightly higher values at the Bottom in some intervals (Figure 6). Therefore, no remarkable vertical movement was detected for this species. A significant positive correlation between $B$. falcatus and water temperature was detected by the Pearson correlation $(\mathrm{r}=0.67 ; \mathrm{p}<0.05)$.

The species $H$. mira did not reveal a vertical migration pattern (Figure 7). A relatively homogenous distribution pattern, similar to that observed for $B$. falcatus, was detected. However, the individuals showed a slight trend towards staying in the Bottom in a few intervals.
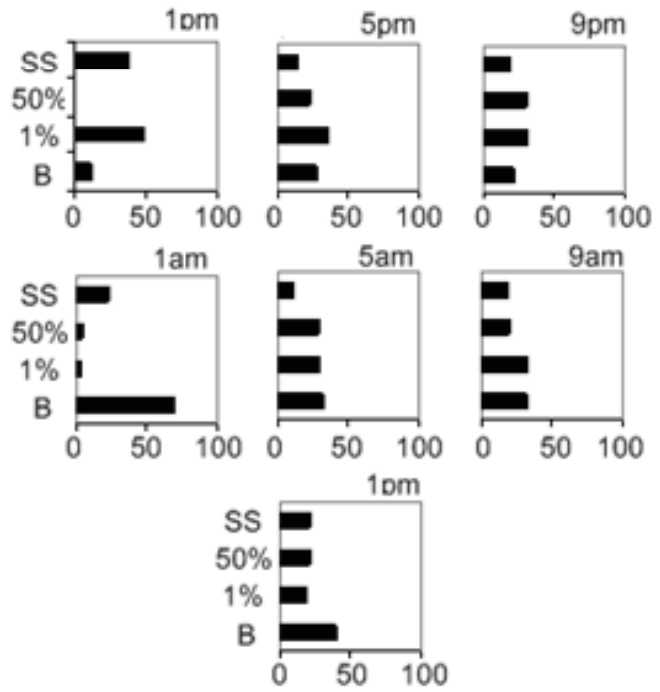

FIGURE 6: Vertical abundance and distribution (\%) of Brachionus falcatus during a diel study at the Bodocongó reservoir, northeastern Brazil. Refer to Figure 3 for legend details.
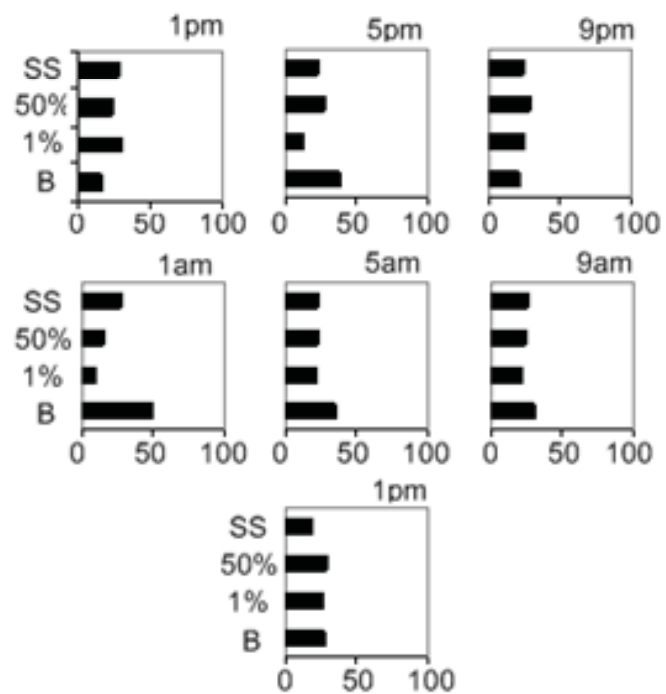

FIGURE 7: Vertical abundance and distribution (\%) of Hexarthra mira during a diel study at the Bodocongó reservoir, northeastern Brazil. Refer to Figure 3 for legend details.

\section{Discussion}

Patterns of diel vertical migration were observed for three of the five examined species, but their relationship with the environmental variables was rather poor. Most Moina minuta individuals migrated to the upper layers of the water column during the late afternoon and showed an equal distribution during the night, staying near the Bottom depth during more 
intense solar radiation. The two cladocerans evaluated, M. minuta and Diaphanosoma spinulosum, showed a fairly similar pattern of distribution. Also, the calanoid copepod Notodiaptomus cearensis showed a somewhat similar pattern of vertical distribution and migration to that of the cladocerans. The positive correlation between $N$. cearensis and M. minuta confirms this similar pattern of distribution. The individuals of these species migrated to the upper layers of the water column from the end of the afternoon through the beginning of the night, and they were homogenously distributed in the water column afterwards. Then, these individuals migrated towards the bottom, where they remained until the end of the study.

No noticeable patterns of vertical migration were detected for Brachionus falcatus and Hexarthra mira. Both species showed a homogenous vertical distribution during most samplings, with only a slight trend towards an increase in the amount of individuals occupying the bottom in a few intervals. The positive correlation between $B$. falcatus and water temperature suggests its preference for warmer waters. Although these species did not show any pattern of vertical migration, the results suggest that they have certain vertical preferences on the water column and that they are able to dislocate fairly well. Paggi (1995), studying the vertical migration of rotifers, found that they had a relatively uniform distribution throughout the water column. As in the present study, he found that the shallow depths and the homogeneity of physical factors along the water column were responsible for the homogenous distribution of the individuals. The correlation of B. falcatus and water temperature may also underpin the fact that no vertical migration was observed for this species, since all depths of the reservoir showed similar high values of water temperature.

Although some authors state that vertical migration is a phenomenon more commonly observed for cladocerans (Stirling et al., 1990; Nogueira and Panarelli, 1997), this study showed that the only copepod species also made significant vertical movements. Of the three types of vertical migration behaviors described by Hutchinson (1967), nocturnal, twilight and reverse, the first type was the only one observed for the cladocerans and the copepod herein. Nocturnal migration is described as the movement of individuals from deeper to superficial layers at night (Hutchinson, 1967) and, according to Bayly (1986), represents the typical type of vertical migration exhibited by most zooplanktonic species.

Despite the great effort in studying vertical migration in different aquatic ecosystems by many authors (e.g. Worthington, 1931; Hutchinson, 1967; Perticarrari et al., 2004), there is still no consensus about the significance of this behavior to the organisms involved and even less on the factors that induce migration. The adaptive value of this behavior, particularly nocturnal migration, may be the avoidance of visual predators located on the surface, thus reducing predation risk, and this is a well accepted explanation by many authors (Zaret and Suffern, 1976; Wright et al., 1980; Stich and Lampert, 1981; Gliwicz, 1986; Ohman, 1990). Alternatively, some species are thought to migrate to the upper layers to feed. For example, Ruttner (1975) showed that the peak of maximum abundance of M. minuta in Lake Castanho (Amazon) was related to an increase of food and also that the rate of growth of this species is greatly related to an increase in the water temperature.

Since the environmental variables evaluated in the present study were homogenously distributed and apparently had only a small influence on vertical migration, it is reasonable to consider other factors as driving forces of vertical migration for the studied species. Although not investigated, explanations involving both avoidance of predators and food consumption may easily be considered to explain the migration of the species of this study. An alternative size-related hypothesis may be one that links the size of the zooplanktonic species that migrate and visualoriented predators. The species that showed vertical patterns of migration were bigger than the ones that did not. These larger species are more susceptible to being detected and eaten by diurnal predators, who use sight to detect and capture prey (Iwasa, 1982). Thus, during the day zooplanktonic individuals tend to stay on the bottom where light penetration is low or absent, and at night and dawn they migrate to the surface where food concentration is higher and predation is minimum. For the smaller species, the problem of being detected is less 
significant and this may explain why the rotifers showed a more homogenous distribution. An additional insight may be gained by looking at species distribution in the 1 am interval, where a higher abundance was observed at the bottom. Although the abundance of Chaoborus species was not estimated, the larvae of these aquatic insects, which are very common in the studied area and are potential predators of many zooplankton species (see Bezerra-Neto and Pinto-Coelho, 2007; Freitas et al., 2007), may have played a role in the reduction of zooplankton abundance in the upper layers of the reservoir. These aspects need to be further investigated. However, regardless of the factors that might actually explain the adaptive significance of the vertical migration strategy, it is clear that light plays a chief role in controlling and promptly inducing vertical migration (Ringelberg, 1980 and 1991).

The present study showed that vertical migration is an important strategy for the zooplankton, even in shallow environments with homogenous distribution of environmental variables. Further, it is important to mention that species distribution was poorly dependent upon environmental fluctuations, supporting the results of some studies, but contesting others (see Dawidowicz et al., 1990; Haney et al., 1990; Tomm et al., 1992; Lampert and Sommer, 1997). From a more rational standpoint, this study supports the idea that the results may vary in correspondingly different scales and communities. Our contribution is one of the few that have investigated vertical migration and its relationship to the environmental variables in the tropical shallow freshwater environments of Brazil. It is also important to mention that it was conducted in an area which has received very little scientific attention lately, despite its historical importance.

\section{Acknowledgments}

Thanks are due to all the people who helped during fieldwork and lab analyses and to two anonymous referees, whose comments and suggestions were of great importance for this study.

\section{References}

Alves, A. G. C.; Souto, F. J. B.; Leite, A. M. 2002. Etnoecologia dos cágados d'água Phrynops spp. (Testudinomorpha: Chelidae) entre pescadores artesanais no Açude Bodocongó, Campina Grande, Paraíba, Nordeste do Brasil. Sitientibus Série Ciências Biológicas, 2: $62-68$.

APHA. 1995. Standard methods for the examination of water and waste water. American Public Health Association, Washington, USA, 953pp.

Bayly, I. A. E. 1963. Parasitic castration of a freshwater calanoid copepod by a cestode cysticercoid stage. Crustaceana, 5: 75-80.

Bayly, I. A. E. 1986. Aspects of diel vertical migration in zooplankton and its enigma variations. In: Deckker, P. D. \& Williams, W. D. (Eds). Limnology in Australia. CSIRO Aust, Melbourne, Australia, p.349-368.

Bezerra-Neto, J. F.; Pinto-Coelho, R. M. 2007. Diel vertical migration of the copepod Thermocyclops inversus (Kiefer, 1936) in a tropical reservoir: the role of oxygen and the spatial overlap with Chaoborus. Aquatic Ecology, 41: 535-545.

Buchanan, C.; Haney, J. F. 1980. Vertical migrations of zooplankton in the Arctic: A test of the environmental controls. In: Kerloot, W. C. (Ed.). Evolution and ecology of zooplankton communities. University Press of New England, Hanover, Germany, p.69-79.

Dawidowicz, P.;Pijanowska, J.; Ciechomshi, K. 1990. Vertical migration of Chaoborus larvae is induced by the presence of fish. Limnology and Oceanography, 35: 1631-1637.

Dodson, S. 1990. Predicting diel vertical migration of zooplankton. Limnology and Oceanography, 35: 1195-1200.

Dussart, B. H.; Defaye, D. 1995. Copepoda. Introduction to the Copepoda. Guides to the identification of the microinvertebrates of the continental waters of the world. Academic Publishing, Amsterdam, Netherlands, 277pp.

Esteves, F. A. 1998. Fundamentos de Limnologia. Interciência FINEP, Rio de Janeiro, Brasil, 602pp.

Fisher, T. R.; McLack, J. M.; Robertson, B.; Hardy, E. R.; Alves, L. F. 1983. Vertical distribution of zooplankton and physico-chemical conditions during a 24-hour period in an amazon floodplain lake Lago Calado, Brazil. Acta Amazonica, 13: 475-487.

Freitas, G. T.; Crispim, M. B. C.; Hernandéz, M. I. M. 2007. Changes in life-history parameters of Cladoceran Ceriodaphnia cornuta (Sars, 1886) in the presence of Chaoborus larvae. Acta Limnologica Brasiliensia, 19: 295-303.

Gliwicz, Z. M. 1986. Predation and the evolution of vertical migration in zooplankton. Nature, 320: 746-748.

Golterman, H. L.; Clymo, R. S.; Ohnstad, M. A. M. 1978. Methods for physical and chemical analysis of freshwater. Blackwell Science Publisher, Oxford, UK, 214pp.

Haney, J. F.; Hall, D. J. 1973. Sugar-coated Daphnia: A preservation technique for Cladocera. Limnology and Oceanography, 18: 331-333.

Haney, J. F.; Craggy, A.; Kimball, K.; Weeks, F. 1990. Light Control of evening vertical migration by Chaoborus punctipennis larvae. Limnology and Oceanography, 35: 1068-1078.

Harding, J. P.; Smith, W. A. 1974. A key to the British freshwater cyclopoid and calanoid copepods. $2^{\text {nd }}$ Freshwater Biological Association, Cumbria, UK, 56pp. 
Hutchinson, G. E. 1967. A treatise on Limnology II. Introduction to Lake Biology and the Limnoplankton. John Wiley \& Sons, New York, USA, 570pp.

Iwasa, Y. 1982. Vertical migration of zooplankton: A game between predator and prey. American Naturalist, 120: 171-179.

Korovchinsky, N. M. 1992. Sididae \& Holopediidae. Guides to the identification of the Microinvertebrates of the Continental Waters of the World. Academic Publishing, The Hague, Netherlands, 82pp.

Lampert, W.; Sommer, U. 1997. Limnoecology: the ecology of lakes and streams. Oxford Academic Press, New York, USA, 400pp.

Mackereth, F. J. H.; Heron, J.; Talling, J. F. 1978. Water analysis: some revised methods for limnologists. Freshwater Biological Association Scientific Publication, 36: 121.

Matsumura-Tundisi, T.; Tundisi, J. G.; Tavares, L. H. S. 1984. Diel migration and vertical distribution of Cladocera in Lake D. Helvécio (Minas Gerais, Brazil). Hydrobiology, 113: 299-306.

Medeiros, P. R.; Barbosa, J. E. L.; Silva, A. M. A.; Crispim, M. C. B. 2007. Vertical and nictemeral dynamics of limnological variables in a tropical Brazilian dam. Revista de Biologia e Ciências da Terra, 7: 73-80.

Meyers, D. G. 1980. Diurnal vertical migration in aquatic microcrustacea: Light and oxygen responses of littoral zooplankton. In: Kerloot, W. C. (Ed.). Evolution and ecology of zooplankton communities. University Press of New England, Hanover, Germany, p.80-90.

Moredjo, A. 1998. Avaliação dos efeitos das atividades humanas sobre o estado trófico dos açudes paraibanos, com ênfase na utilização da comunidade zooplanctônica como bioindicador. Dissertação de Mestrado, Universidade Federal da Paraíba, Brasil, 136pp.

Nogueira, M. G.; Panarelli, E. 1997. Estudo da migração vertical das populações zooplanctônicas na represa de Jurumirim (Rio Paranapanema - São Paulo, Brasil). Acta Limnologica Brasiliensia, 9: $55-81$.

Ohman, M. D. 1990. The demographic benefits of diel vertical migration by zooplankton. Ecological Monographs, 60: 257-281.

Paggi, S. J. 1995. Vertical distribution and diel migration of rotifers and in a Paraná River floodplain lake. Hydrobiology, 310: 87-94.

Pennak, R. W. 1978. Fresh-water invertebrates of the United States. John Wiley and Sons, New York, USA, 803pp.

Perticarrari, A.; Arcifa, M. S.; Rodrigues, R. A. 2004. Diel vertical migration of copepods in a Brazilian lake: A mechanism for decreasing risk of Chaoborus predation? Brazilian Journal of Biology, 64: 289-298.

Reid, J. W. 1985. Chave de identificação e lista de referências bibliográficas para as espécies continentais sul americanas de vida livre da ordem Cyclopoida (Crustacea, Copepoda). Boletim de Zoologia, Universidade de São Paulo, 9: 17-143.
Ringelberg, J. 1980. Introductory remarks: Causal and teleological aspects of diurnal vertical migration. In: Kerfoot, W. C. (Ed.). Evolution and ecology of zooplankton communities. University Press of New England, Hanover, Germany, p.65-68.

Ringelberg, J. 1991. The relation between ultimate and proximate aspects of diel vertical migration in Daphnia hyalina. Internationale Vereinigung fur theoretische und angewandte Limnologie Verhandlungen, 24: 2804-2807.

Rocha, O.; Matsumura-Tundisi, T. 1976. Atlas do zooplâncton (Represa do Broa, São Carlos) I - Copepoda. Universidade Federal de São Carlos, Brasil, 68pp.

Rodier, J. L. 1975. Analyse de l'eau: Eaux naturelles, eaux residuals, eaux de mer. Dunod, Paris, France, 692pp.

Ruttner, F. 1975. Fundamentals of Limnology. University of Toronto Press, Toronto.

Sekino, T.; Yamamura, N. 1999. Diel vertical migration of zooplankton: Optimum migrating schedule based on energy accumulation. Evolutionary Ecology, 13: 267-282.

Stich, H. B.; Lampert, W. 1981. Predation evasion as an explanation of diurnal vertical migration by zooplankton. Nature, 293: 396-398.

Stirling, D. G.; McQueen, D. J.; Johannes, R. S. 1990. Vertical migration in Daphnia galeata mendotae (Brooks): Demographic responses to changes in planktivore abundance. Canadian Journal of Fisheries and Aquatic Sciences, 47: 395-400.

Tomm, I.; Pozzobon, M. G. G.; Dalla-Costa, M. L. S. R.; LansacTôha, F. A. 1992. Distribuição vertical nictemeral de crustáceos planctônicos em um braço do Reservatório de Itaipu- PR. Revista UNIMAR, 14: 57-22.

Worthington, E. B. 1931. Vertical movements of fresh-water macroplankton. Internationale Revue der Gesamten Hydrobiologie, 25: 394-436.

Wright, S. 1934. Alguns dados da phisica e da chimica das águas dos açudes nordestinos. Boletim da Inspectoria Federal de Obras Contra as Secas, 1: 164-169.

Wright, S. 1936. Thermal conditions in some waters of northeast Brazil. Anais da Academia Brasileira de Ciências, 8: 163-167.

Wright, D.; O'Brien, W. J.; Vinyard, G. L. 1980. Adaptive value of vertical migration: A simulation model argument for the predation hypothesis. In: Kerloot, W. C. (Ed.). Evolution and ecology of zooplankton communities. University Press of New England, Hanover, Germany, p.138-147.

Zaret, T. M.; Suffern, J. S. 1976. Vertical migration in zooplankton as a predator avoidance mechanism. Limnology and Oceanography, 21: 804-813. 